Vol. 2:22-26, December 2016

DOI: http://dx.doi.org/10.3126/jnarc.v2i0.16117

\title{
Biovar Differentiation and Variation in Virulence of Ralstonia solanacearum Isolates Infecting Solanaceous Vegetables
}

\author{
Ram Devi Timila* and Shrinkhala Manandhar \\ Plant Pathology Division, Nepal Agricultural Research Council, Khumaltar, Lalitpur, Nepal \\ *Corresponding: rtimila@gmail.com
}

Received July 2015; Revised August 2016; Accepted October 2016

Scientific Editors: CB Karki, Tek B. Gurung

Copyright @2016 NARC. Permits unrestricted use, distribution and reproduction in any medium provided the original work is properly cited

\begin{abstract}
Bacterial wilt caused by Ralstonia solanacearum E.F. Smith is one of the destructive diseases of solanaceous vegetables specially tomato (Lycopersicon esculentum L.) and eggplant (Solanum melongena L.). Experiments were conducted to determine biovar types existing among the strains or isolates of Nepal and variation in virulence in some vegetables belonging to solanaceae family. A total of 39 isolates infecting tomato, eggplant, chilli and potato collected from different parts of Nepal were analyzed for biovar types on the basis of 3 disaccharides and 3 hexose alcohols oxidation test. Experiments were conducted to determine variation in virulence or aggressiveness of some of the isolates under screen house conditions using three host differentials such as Pusa Ruby (susceptible), Bishesh (moderately resistant) and Srijana (resistant) tomato cultivars. Of the 39 isolates, 23 were biovar III, three biovar II, three biovar IV, and one was biovar I. Nine isolates could not be differentiated into any of the five biovars. For breeding and epidemiological purposes it is very important to analyze the variability of aggressiveness. A total of 5 isolates collected from different places were included in the test. Isolates from Bhaktapur was found the most virulent causing wilt in the variety Bishesh (moderately resistant). Other isolates had the negative impact with zero wilt on the differentials used. Isolates from Jungekhola of Dhading district did not induce wilt even on susceptible variety (Pusa Ruby), but exhibited only senescence reaction. The result indicated that there is some slight variation among the isolates tested. Some effective management tactics might be needed in those locations where highly aggressive or virulent strain of bacterial wilt is prevalent, because resistant variety may not be stable in such locations.
\end{abstract}

Key words: Bacterial wilt, Biovar, Ralstonia solanacearum, Strain, Virulence,

\section{सारांश}

राल्स्टोनिया सोलानासियारम् नामक शाकाणुद्वारा लाग्ने ओईलाउने रोग सोलानेसी परिवारको बाली खासगरी गोलभेंडा र भण्टा बालीको लागि विनाशकारी रोग हो । तथापि, यी शाकाणु हरु बारे प्रयाप्त जानकारी उपलब्ध नभएको ले उक्त शाकाणुको प्रजाति र बायोभार समूह र तिनीहरुको रोग्याउने क्षमतामा भिन्नता छ, छैन छुट्याउन हेर्न तीन वटा डाईसाकाराइडस् र तीन वटा हेक्सोज अल्कोहलहरुको अक्सिडेसनको आधारमा वायोभार परीक्षण गरियो।। त्यस्तै गोलभेंडाको रोग अवरोधक जात (सिर्जना), मध्यम रोग अवरोधक जात (विशेष) र रोग सशक्त जात (पुसा रुबी) को प्रयोग गरी जाली घरमा केही आईसोलेटहरुको रोग्याउने क्षमता परीक्षण गरियो। परीक्षणको नतिजा अनुसार संकलित ३९ आईसोलेटहरु मध्य २३ वटा वायोभार (३, ३ वटा वायोभार (४ र १ वटा वायोभार ( 9 भएको पाईयो भने $\rho$ वटा आईसोलेटहरु $y$ वटा वायोभार मध्ये कुनै समहमा छुट्याउन सकिएन। बाली प्रजनन तथा ईपिडेमियोलोजीको लागि रोगको जीवाणुको रोग्याउने क्षमतामा भिन्नताको विश्लेषणको महत्वपूर्ण भूमिका हुन्छ। प्रयोग गरिएका $y$ वटा आईसोलेटहरु मध्ये भक्तपुरबाट संकलित आईसोलेट रोग्याउनमा सबैभन्दा बढी सशक्त भएको पाईयो। जुँगेखोला र धादिङबाट संकलित आईसोलेटहरुले रोग सशक्त जात पुसा रुबीलाई समेत ओईलाउन सकेन र पातहरु पहेंलो मात्र भए । निश्कर्षमा परीक्षणमा समावेश गरिएका शाकाणुको ती $y$ वटा वायोभारहरुको रोग्याउने क्षमतामा केही भिन्नता भएको पाईयो । रोग्याउने क्षमता बढ़ी आक्रामक शाकाणुबाट ओईलाउने रोग लागेको क्षेत्रमा रोग व्यवस्थापनको लागि बिभिन्न थप उपचार बिधिहरुको प्रयोग गर्न आवश्यक रहेको र पर्दछ पर्ने भएकोले रोग अवरोधक जातको रोग अवरोध गर्न सक्ने क्षमता मा क्रमिक ह्रास आउने हुन्छ भन्ने निर्कयोल गरियो।

\section{INTRODUCTION}

Bacterial wilt caused by Ralstonia solanacearum E.F. Smith in tomato is widely distributed disease in the world. It is one of the limiting factors to successful cultivation of solanaceous vegetables throughout the world, especially in prevalent areas with warm and humid climate (Kelman 1953, Vawdrey and Gounder 1993). In Nepal, bacterial wilt is prevalent in tarai, inner tarai and foot hill areas where tomato (Lycopersicon esculentum Mill.), eggplant (Solanum melongena L.) and potato (Solanum tuberosum L.) are grown (Thapa and Manandhar, 1992). The bacterial wilt seems to be the third most important disease in tomato after late blight and viral disease complex; while probably the first in eggplant. In tomato crop, it was first recorded in 1978 (Shrestha 1990). The disease is not observed as a problem in winter tomato production in tarai, because of low air temperature and high soil moisture thereby (Timila et al 1997). The incidence of wilt in tomato and potato was reported to be as high as 100\% and 70\% (Adhikari et al 1993) respectively. In some locations, more than $80 \%$ disease incidence was observed in tomato whereas up to $40 \%$ in eggplant (Timila et al 1997). Thus, the wilt disease is location and strain specific with environmental conditions. Bacterial wilt is a difficult disease to control. Once established in a field it is more challenging to control this pathogen, because of wide host range (covering more than 44 plant families) and ability to survive in the soil for long time with vast genetic variability of the pathogen (Hayward 1991). The primary source of inoculum for the occurrence and spread of the disease is considered to be infested soil, plant debris, weed hosts, seeds, vegetative propagative materials, contaminated water and farm tools (IPDN 2014). Although different biovars and virulent strains of $R$. solanacearum cause most economic wilt disease for the vegetables belonging to solanaceae family, however, much information on these has yet to be documented, classified and managed to control them. Therefore, in present work we aimed to determine variability in virulence of $R$. solanacearum, biovars and their distribution in Nepal. 
Vol. 2:22-27, December 2016

DOI: http://dx.doi.org/10.3126/jnarc.v2i0.16117

\section{MATERIALS AND METHODS}

\section{Biovar differentiation}

Ralstonia solanacearum from wilted plants of tomato, eggplant, chilli, and potato collected from different locations of Nepal were isolated in Tetrazolium chloride (TZC) medium (Casamino acid 1.0g, Bacto-peptone 10.0g, Dextrose 5.0g, Agar 15.0g, Distilled water 1 liter). The colonies in the medium appeared fluidal white with pink centers. Such a typical single colony from each isolate was multiplied or cultured on 523- medium $\left(\mathrm{MgSO}_{4}\right.$. $7 \mathrm{H} 2 \mathrm{O} 0.3 \mathrm{~g}, \mathrm{~K}_{2} \mathrm{HPO}_{4} 2 \mathrm{~g}$, Yeast extract $4 \mathrm{~g}$, Casein hydrolysate $8 \mathrm{~g}$, Sucrose $10 \mathrm{~g}$, Agar $18 \mathrm{~g}$ and Distilled water 1 liter) as described by Asian Vegetable Development and Research Center (AVRDC 1992). Biovar determination was done on the basis of carbon source utilization with disaccharides and hexose alcohols. A total of 39 isolates were subjected for biovar differentiation using Hayward's medium (Hayward,1964) $\div\left(\mathrm{NH}_{4} \mathrm{H}_{2} \mathrm{PO}_{4} 1.0 \mathrm{~g}, \mathrm{KCL} 0.2 \mathrm{~g}, \mathrm{MgSo}_{4} .7 \mathrm{H}_{2} \mathrm{O} 0.2 \mathrm{~g}, \mathrm{Peptone}\right.$ $1.0 \mathrm{~g}$, Bromothymol blue $10.2 \mathrm{ml}$, Distilled water $1 \mathrm{~L}$ ) as basal medium supplemented with $10 \%$ six different carbon sources in disaccharides and hexose alcohols (cellobiose, lactose, maltose, dulcitol, mannitol and sorbitol) in two lots. A drop of turbid suspension of each isolate was inoculated in the basal medium supplemented with disaccharides or hexose alcohols in duplicate sets. The basal medium without disaccharides served as the control. The inoculated tubes with different isolates were incubated at $28^{\circ} \mathrm{C}$. Observation was taken for the change in colour of the medium from olive green to yellow and continued for two weeks. Change in colour to yellow indicates the positive reaction that is utilization of carbon source as given in the following table. The test was conducted in two replications. And some of the isolates were tested repeatedly.

Table 1. Biovar differentiation of Ralstonia solanacearum based on utilization of various carbon sources (IPDN, 2014)

\begin{tabular}{lccccc}
\hline \multirow{2}{*}{ Test carbon sources } & \multicolumn{7}{c}{ Biovars } \\
\cline { 2 - 6 } & $\mathbf{1}$ & $\mathbf{2}$ & $\mathbf{3}$ & $\mathbf{4}$ & $\mathbf{5}$ \\
\hline Maltose & - & - & + & + & + \\
Lactose & - & - & + & + & - \\
Cellobiose & - & - & + & + & - \\
Mannitol & - & + & + & - & + \\
Sorbitol & - & + & + & - & + \\
Dulcitol & - & + & + & - & + \\
\hline
\end{tabular}

\section{Variability in virulence}

In the experiment, the tomato differential host plants used were three tomato varieties, Pusa Ruby (susceptible), Bishesh (Makis) (moderately resistant) and Srijana (the resistant). Under screen house conditions, seedlings were raised by direct sowing in 3 inch plastic pots using steam sterilized soil. Only one seedling per pot was maintained. For each strain of the bacterium, 12 seedlings were used.

Five isolates of $R$ solanacearum (RS) from tomato and eggplant collected from different locations were isolated and used in the study. Isolation, multiplication and storage of RS were done as mentioned above in biovar differentiation. For reviving, the isolates were streaked in TZC medium separately and incubated at $28^{\circ} \mathrm{C}$ for 48 hours for single colony development. Then a single colony was multiplied in 523-medium as mentioned above. After 24 hours, bacterial mass of each isolate was suspended in sterile distilled water and the concentration was estimated at $\mathrm{OD}_{600}=0.300\left(1 \times 10^{8)}\right.$ colony forming units per $\mathrm{ml}$ for inoculation.

Inoculation was done on six weeks old seedling. Before inoculation one time watering was skipped to reduce moisture in pots. Root system of each seedling was injured with a sharp knife inserting through the soil at one side of the seedling so as to wound the root to facilitate bacterial entry. Inoculation of each RS isolate in each host differential (variety) was done by pouring $30 \mathrm{ml}$ of bacterial suspension at the base of each seedling. Watering was done normally the next day.

Wilt incidence percent was determined by counting the number of infected plants against total number of plants of each variety and for each bacterial strain. Evaluation was started by recording wilted plants at 3, 6, 9, 12 and 15 days after inoculation.

\section{RESULTS}

\section{Biovar Differentiation and Distribution}

Based on the ability of oxidizing disaccharides and hexose alcohol test, isolates were grouped into different biovars. Out of the 39 isolates collected from different solanaceous vegetable crops, 23 were identified as biovar III, three were as biovar II, three as biovar IV and one as biovar I. Nine isolates could not be differentiated into any of the five biovars in oxidizing hexose alcohols according to biovar differentiation norms (Figure 1). Òf the 9 isolates, three tomato isolates from Charaali, Jhapa, Rampur, Chitwan and Dhulikhel, Kavrepalanchowk district did not oxidize dulcitol. One from Mahadev Besi of Kavrepalanchok district oxidized only sorbitol. Some of the isolates were found oxidizing only mannitol (Table 1,2). The results indicated the prevalence of biovar I and IV also in Nepal. However, most of the isolates infecting tomato and eggplant were biovar III. Biovar II of tomato isolates were from Lele and Dhulikhel where potato is widely cultivated. This biovar II isolate was recorded from Lele in grafted tomato in wild eggplant (Solanum sisymbriifolium Lam.) which is used as resistant root stock against bacterial wilt. According to He et al (1983), the strains from mulberry do not oxidize dulcitol and sorbitol, thus grouped as biovar V. Similarly, the isolate from chilli from Charaali, Jhapa and potato from Nala, Kavrepalanchowk oxidized only mannitol (Table 2). These indicate that collection of more isolates and testing them for biovar separation are necessary.

\section{Variability in Virulence}

The data presented in Table 3 showed variable reactions to wilt by different isolates in the most susceptible variety, Pusa Ruby. Wilting started in Pusa Ruby three days after inoculation with isolate from Bhaktapur. With the same isolate, wilting started in moderately 
resistant variety, Bishesh, 6 days after inoculation and induced up to $33 \%$ wilt incidence. The other isolates such as isolate from Gongabu, Kathmandu and Dharke, Dhading, induced wilting in Pusa Ruby after a week of inoculation. The disease progressed to $100 \%$ by Bhaktapur isolate. The rate of disease progress remained stable in Bishesh variety by Bhaktapur isolate after 6 days of inoculation (Figure 2), whereas, the disease progressed to $83 \%$ and $67 \%$ by Gongabu (Kathmandu district) and Dharke (Dhading district) isolates, respectively (Table 3). The isolates from Jungekhola and Lele did not induce disease even in susceptible variety; Pusa Ruby but showed only senescing reaction. None of the test isolates induced wilt in Srijana variety. Slight variation in virulence in inducing wilt was found with different isolates.

Table 1. Biovar differentiation of the Ralstonia solanacearum strains isolated from Tomato from different locations of Nepal (Tested in different years, 2001, 2012-2014)

\begin{tabular}{|c|c|c|c|c|c|c|c|c|c|}
\hline \multirow{2}{*}{ Isolate } & \multirow{2}{*}{ Location } & \multicolumn{7}{|c|}{ Disaccharides Year Alcohols } & \multirow{2}{*}{ Biovar } \\
\hline & & Maltose & Lactose & Cellobiose & Mannitol & Sorbitol & Dulcitol & Control & \\
\hline $\mathrm{T} 1$ & Rupani, Saptar, & + & + & + & + & + & + & _- & III \\
\hline $\mathrm{T} 2$ & Jhapa & + & + & + & + & + & - & _ & $*$ \\
\hline T3 & Thankot, Kathmandu & _ & _ & __ & __ & _ & _ & _ & $\mathrm{I}$ \\
\hline $\mathrm{T} 4$ & Panchkhal, Kavre & + & + & + & + & + & + & _- & III \\
\hline T5 & Godamchour, Lalitpur & + & + & + & + & + & + & _- & III \\
\hline T6 & Chitwan & + & + & + & + & + & _ & _ & $*$ \\
\hline $\mathrm{T} 7$ & Yampaphant, Tanahun & + & + & + & + & + & + & - & III \\
\hline $\mathrm{T} 8$ & Thaiba Lalitpur & + & + & + & + & + & + & _ & III \\
\hline T9 & Keraghari, Kavre & + & + & + & + & + & + & _ & III \\
\hline $\mathrm{T} 10$ & Koteshwor, Kathmandu & + & + & + & + & + & $\ldots$ & _- & $*$ \\
\hline T11 & Khumaltar, Lalitpur & - & _- & _ & + & + & + & _ & IV \\
\hline T12 & Panchkhal, Kavre & + & + & + & + & + & + & - & III \\
\hline T13 & Nala, Kavre & + & + & + & __ & $\ldots$ & _ & _ & II \\
\hline $\begin{array}{l}\mathrm{T} 14 \\
\end{array}$ & Khumaltar 2, Lalitpur & + & + & + & + & + & + & _ & III \\
\hline T15(SS) & Lele, Lalitpur & + & + & + & _- & _ & - & - & II \\
\hline T16 & Dhulikhel, Kavre & + & + & + & + & + & _ & _ & $*$ \\
\hline T17 & Mahadevbesi, Kavre & - & - & _- & _ & + & _ & 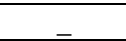 & $* * *$ \\
\hline T18 & Luvu, Lalitpur & + & + & + & + & + & + & _ & III \\
\hline T96 & Machhegaoun, Kathmandu & + & + & + & + & + & + & _ & III \\
\hline $\mathrm{T} 20$ & Chhatredeu-rali, Dhading & + & + & + & + & + & + & _- & III \\
\hline $\mathrm{T} 21$ & Hemja, Kaski & + & + & + & + & + & + & - & III \\
\hline $\mathrm{T} 22$ & Jungekhola, Dhading & $\ldots$ & $\ldots$ & $\ldots$ & + & + & + & 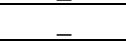 & IV \\
\hline $\mathrm{T} 23$ & Aarukharka, Syanjya & + & + & + & + & + & + & & III \\
\hline $\mathrm{T} 24$ & Malepatan, Kaski & + & + & + & + & + & + & & III \\
\hline
\end{tabular}

Table 2. Biovar differentiation of the Ralstonia solanacearum strains isolated from different Solanaceous vegetable crops from different locations of Nepal (tested in different years)

\begin{tabular}{|c|c|c|c|c|c|c|c|c|c|}
\hline \multirow{2}{*}{$\begin{array}{l}\text { Isolate } \\
\text { /crop }\end{array}$} & \multirow{2}{*}{ Location } & \multicolumn{7}{|c|}{ Disaccharides and hexose alcohols } & \multirow{2}{*}{ Biovar } \\
\hline & & Maltose & Lactose & Cellobiose & Mannitol & Sorbitol & Dulcitol & Control & \\
\hline E1 & Surunga, Morang & + & + & + & + & + & + & - & III \\
\hline E2 & Dipayal, Doti, & + & + & + & + & + & + & - & III \\
\hline E3 & Bhokrah, Sunsari & + & + & + & + & + & _ & - & $*$ \\
\hline E4 & Tarahara, Sunsari & + & + & + & + & + & _- & - & $*$ \\
\hline E5 & Kathmandu & + & + & + & + & + & + & - & III \\
\hline E6 & Chapagaoun, Lalitpur & + & + & + & + & + & + & - & III \\
\hline E7 & Katunje, Bhaktapur & + & + & + & + & + & + & - & III \\
\hline E8 & Badegaoun, Lalitpur & + & + & + & + & + & + & - & III \\
\hline E9 & Balanko, Bhaktapur & + & + & + & + & + & + & - & III \\
\hline $\mathrm{C} 1$ & Rupani, Saptari & - & - & - & + & + & + & - & IV \\
\hline $\mathrm{C} 2$ & Charaali, Jhapa & - & - & - & + & - & - & - & $* *$ \\
\hline $\mathrm{C} 3$ & Kumfur, Dhading & + & + & + & + & + & + & - & III \\
\hline $\mathrm{C} 4$ & Ugrachandi, Kavre & + & + & + & + & + & + & - & III \\
\hline P1 & Nala, Kavre & - & - & - & + & - & - & - & $* *$ \\
\hline $\mathrm{P} 2$ & Indrayani, Kathmandu & + & + & + & - & - & - & - & II \\
\hline
\end{tabular}


Vol. 2:22-27, December 2016

DOI: http://dx.doi.org/10.3126/jnarc.v2i0.16117

Table 3. Variation in the virulence of Ralstonia solanacearum isolates collected from different places (2014)

\begin{tabular}{l|l|l|l|l|l}
\hline \multirow{2}{*}{ SN } & \multirow{2}{*}{ R. Solanacearum Isolates/crop } & \multirow{2}{*}{ Locations of collection } & \multicolumn{4}{|c}{ Wilt incidence percent in different tomato differential host } \\
\cline { 3 - 6 } & & & Pusa Ruby & Bishesh & Srijana \\
\hline 1 & Grafted tomato & Lele, Lalitpur & Yellowing only & 0.00 & 0 \\
\hline 2 & Eggplant & Katunje, Bhaktapur & 100.00 & 33.33 & 0.00 \\
\hline 3 & Tomato & Jungekhola, Dhading & Yellowing only & 0.00 & 0.00 \\
\hline 4 & Tomato & Gongabu, Kathmandu & 83.33 & 0.00 & 0.00 \\
\hline 5 & Tomato & Dharke, Dhading & 66.66 & 0.00 & 0.00 \\
\hline 6 & Negative control (water inoculated) & - & 0.00 & 0.00 & 0.00 \\
\hline
\end{tabular}

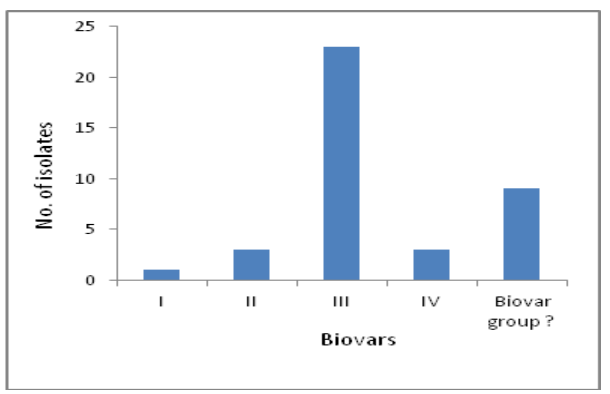

Figure 1. Frequency distribution of different biovars of Ralstonia solanacearum isolates infecting solanaceous vegetable crops.

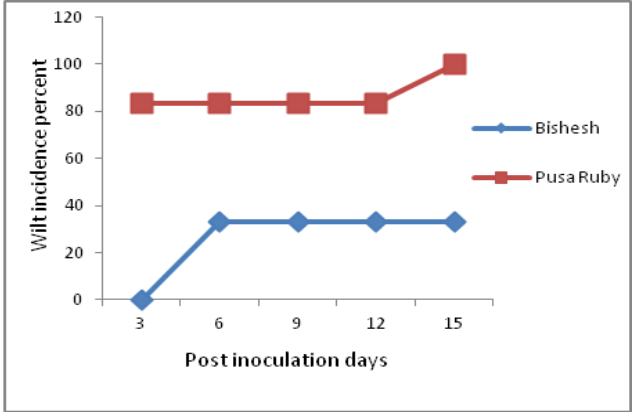

Figure 2. Disease progress curve caused by Bhaktapur isolate of Ralstonia solanacearum in Pusa Ruby and Bishesh variety of tomato.

\section{DISCUSSION}

Strains of $R$. solanacearum have been grouped into five races based on host plants susceptibility and biovar classification such as Race 1 biovar 1, 3, 4; race 2 biovar 1; race 3 biovar 2; race 4 biovar 3, 4 and race 5 biovar 5 with specific geographic distribution (Denny and Hayward 2001). In Nepal, Race 1, biovar III in tomato/eggplant and, biovar IV in chilli/ tomato crops and Race 3 biovar II in potato are the prevalent strains of $R$. solanacearum (Timila and Shrestha 2001, Shrestha 1977, Timila et al 1997, Adhikari et al 1997). In recent years, based on DNA sequence analysis, $R$. solanacearum species complex has been divided into four phylotypes, phylotype I to IV originated in Asia, America, Africa, and Indonesia respectively (IPDN, 2014). Concerning the degree of disease incidence and severity induced by $R$. solanacearum, it is related to its degree of virulence. Wilt incidence and degree of severity of the disease could be affected by temperature as mentioned by Mew and Ho (1976). However, during experimental period, temperature was ranged from $28^{\circ}-$ $30^{\circ} \mathrm{C}$, which is ideal for the growth of the given pathogen and disease development. Bhaktapur isolate (Katunje location) was the aggressive isolate and caused the disease up to 33\% incidence in moderately resistant variety (Bishesh). Previously, Timila (2008) reported the existence of variation in aggressiveness of the isolates from tomato. The highly aggressive strain/isolate from western Nepal (Myagdi) caused the wilt in resistant variety (L 986).Less aggressiveness of $R$. solanacearum strains on tomato is more related to have slower multiplication rate rather than upward movement of bacteria in the plant (Wang et al 2005). Bacterial wilt disease was lowered as the seedling age increased (Timila 2005). Since older plants are less susceptible to wilt than younger ones or the infection could be latent in older plants (Tung et al 1990). In present study, one of the reasons of lower wilt incidence or lesser virulent expression of the tested isolates could be due to over aged seedlings during inoculation as compared to normal seedlings of 4-5 weeks. Virulence differences among pathogen strains can cause instability in host resistance although other biotic and abiotic factors also affect host resistance (Hayward 1991). The virulence of the strain is related to its aggressiveness on the susceptible cultivar. Among the races of $R$. solanacearum, race 1 is the most diverse group and a large variation in both genotypes and aggressiveness has been observed in several race 1 populations (Prior et al 1990, Hayward 1991). Aggressiveness of the strain is highly concerned with the management of bacterial wilt. Degree of aggressiveness plays an important role in breeding and epidemiology of the disease (Darrasse et al 1997) as well as its understanding has implications in the development of management strategies. The least aggressive strain affects least on the resistant cultivar (AVRDC 1991). It is quite obvious that the bacterial wilt disease in tomato is continuing to be important in tomato growing areas of Nepal. Since the wilt pathogen is soil borne thus, it is very difficult to control. Currently, in Nepal, wide adoption of cultivation of Srijana variety (resistant F1) by the farmers has lowered bacterial wilt disease in most of the tomato cultivating areas. The use of resistant varieties is one of the best method of bacterial wilt control, but resistance can vary among different geographic locations depending on the virulence of the bacterial strain present (Kelman and Person 1961). Location specific nature of resistance to bacterial wilt could be due to difference in the aggressiveness of the pathogen strains, climate and soil characteristics present in the location (Wang et al 1997). Therefore, a single method will not be effective in controlling bacterial wilt in tomato (Hartman 1992). Hence, in association with the use of resistant variety, a number of other management tactics might be needed in those locations where highly aggressive strain of bacterium is prevalent, because resistant variety may not be stable for long in such locations. Due to the variation in virulence of the bacterial wilt pathogen, the programs for improvement of tomatoes for resistance to bacterial wilt should include all groups of strains prevalent in the given area (Prior et al 1990). 
Vol. 2:22-26, December 2016

DOI: http://dx.doi.org/10.3126/jnarc.v2i0.16117

\section{CONCLUSION}

The present study indicated that there is existence of biovar I, II, III and IV in Nepal and distributed both in the hills and in the tarai, however, the isolates collected were mostly from the hills. There are some variation in the virulence among the strains which belong to race 1 , biovar 3. Only a few isolates were included in the study, thus more isolates are needed to be studied for greater detail on degree of virulence of the $R$. solanacearum strains. Such studies can help develop tomato wilt management strategy for different agroecological regions of the country.

\section{ACKNOWLEDGEMENT}

The authors are thankful to the colleagues of Plant Pathology Division, Nepal Agriculture Research Institute, NARC for their suggestions and comments on draft version of this paper. Thanks go to Ms. Pushpa Shrestha and Ms. Kamala Shrestha for their assistance in the laboratory and screen house experimental works.

\section{REFERENCES}

Adhikari TB, JB Manandhar and GL Hartman. 1993. Characterization of Pseudomonas solanacearum and evaluation of tomatoes in Nepal. Bacterial Wilt ACIAR Proc. 45:132-136.

Adhikari TB, R Basnyat and AR Smith. 1997. Current status of Pseudomonas solanacearum research in Nepal. Abstract of the paper presented in the 5th International Conference on Pseudomonas syringae pathovars and related pathogen, Sept. 3-8, 1995, Berlin, Germany.

AVRDC .1991. Progress Report 1990. Asian Vegetable Research and Development Center, Shanhua Tainan, Taiwan 305Pp.

AVRDC .1992. Progress Report 1991. Asian Vegetable Research and Development Center,, Shanhua,Tainan, Taiwan, 410Pp.

Darrasse A, A Trigalet and P Prior. 1997. Aggressiveness of Ralstonia solanacearum race 1 and correlation with pathogen genomic variation. http//www.inra.fr/internet. Departments/PATHOV/2 ${ }^{\text {nd }}-$ IBWS/A17.html

Denny TP and AC Hayward. 2001. Gram negative bacteria. In Laboratory Guide for identification of plant pathogenic bacteria, edited by NW. Schhad, J.B. Jones and W. Chun.St Paul, Minnesota: APS Press.

Hartman GL. 1992. Control of Bacterial wilt. Lecture 2. SAVERNET Bacterial Wilt Training Course Manual. Asian Vegetable Research and Development Center. Oct. 5-Nov. 16,1992.

Hayward AC. 1991. Biology and epidemiology of bacterial wilt caused by Pseudomonas solanacearum. Annul. Rev. Phytopatho. $29: 65-67$.

He LY, L Sequeira and A Kelman 1983. Characteristics of strain of Pseudomonas solanacearum from China. Plant Disease 67(12): 1357-1361. http://www.inra.fr/internet.Departements/PATHOV/2nd_IBWS/A17.html

IPDN.2014. Bacterial Wilt Disease, Ralstonia solanacearum. Standard Operating Procedure for Use in Diagnostic Laboratories. Version: EASOP-RSI. IPDN

Kelman A. 1953. The Bacterial wilt caused by Pseudomonas solanacearum. North Carolina Agricultural Experiment Station Technical Bulletin.99. 194pp.

Kelman A. and IH. Pearson. 1961. Strains of Pseudomonas solanacearum differing in pathogenecity to tobacco and peanut. Phytopathology $51: 158-161$

Mew TW and Ho WC. 1976. Varietal resistance to bacterial wilt in tomato. Plant Disease Reporter. 60(3):204-208.

Prior P, H Steva and P Cadet. 1990. Aggressiveness of strains of Pseudomonas solanacearum from the French Westr Indies (Martinique and Guadeloupe) on tomato. Plant Dis. 74:962-965

Shrestha K. 1990. Major diseases of vegetable crops in Nepal. (Nepali book). g]kfndf t/sf/L afnLsf d'Vo /f]ux? . Vegetable Development Division, HMG/Fresh Vegetable and Vegetable Seed Production Project, FAO, Khumaltar Lalitpur Nepal. 111pp.

Shrestha SK. 1977. Preliminary study on brown rot of potatoes in Nepal. Nepalese Journal of Agriculture 12:11-21.

Thapa BJ and HK Manandhar. 1992. Bacterial diseases. In: Plant Diseases, Seed Production and Seed Health Testing in Nepal (SB Mathur, P Amatya, Krishna Shrestha and HK Manandhar eds). Proc. of the First HMG/DANIDA/FAO Training Course in Seed Health Testing Techniques, 5-19 Dec. 1989 Khumaltar Lalitpur, Nepal. Danish Government Institute of Seed Pathology for Developing Countries, Denmark, and Plant Pathology Division, NARC, Nepal. pp. 31-40.

Timila RD. 2005. Prospects of seedling age for the management of bacterial wilt in tomato. Nepal Journal of Plant Sciences. 1:143-146.

Timila RD and K Shrestha. 2001. Sources of resistance to bacterial wilt in tomato and its management (HK Manandhar, CL Shrestha, RK Shrestha and SM Pradhan eds.). In: Proceedings of the First SAS N/Convention March 29-31, Khumaltar, 1999. Society of Agricultural Scientists (SAS) Nepal, January 2001. pp.161-167.

Timila RD, K Shrestha and S Joshi. 1997. Bacterial wilt of tomato and brinjal in Nepal. In: Proc. of the Phase I Final Workshop of the SAVERNET. AVRDC Pub. No. 97-458. pp.156-167.

Timila RD. 2008. Variation in Aggressiveness of Some Isolates of Ralstonia solanacearum on Tomato. Nepalese Horticulture. 6(1):46-51.

Tung PX, Vander Zaag P and EJ Chujo. 1990. Influence of plant age at inoculation on expression of resistance to wilt caused by Pseudomonas solanacearum in potato. Bacterial Wilt Newsletter 6:1-2.

Vawdrey LL and RK Gounder. 1993. A glasshouse seedling test for bacterial wilt resistance in tomato. Bacterial Wilt Newsletter No. 9:3.

Wang JF and CH Lin. 2005. Colonization capacity of Ralstonia solanacearum tomato strains differing in aggressiveness on tomatoes and weeds. In: Bacterial wilt disease and the Ralstonia solanacearum species complex (Caitilyn Allen, Philippe Prior and A.C Hayward, eds). pp.73-79

Wang J-F, P Hanson and JA Barnes. 1997. Worldwide evaluation of an international set of resistance sources to bacterial wilt in tomato. 269-275 in: Bacterial Wilt Disease: Molecular and Ecological Aspects. P Prior, C Allen, and J Elphinstone, eds. Springer-Verlag, Berlin, Germany 